\title{
Prevention of enzymatic browning of yacon flour by the combined use of anti-browning agents and the study of its chemical composition

\author{
Oscar Romero Lopes RODRIGUES ${ }^{1}$, Eduardo Ramirez ASQUIERI ${ }^{1}$, Daniela Castilho ORSI ${ }^{2 *}$
}

\begin{abstract}
Yacon roots present functional properties because of the high levels of fructooligosaccharides (FOS), which are considered as prebiotic fibers. In addition, yacon roots are rich in phenolic compounds. During the processing of yacon, the freshly cut surface undergoes rapid enzymatic browning. Control of enzymatic browning during processing is very important to preserve the appearance of yacon flour. In this study, it was evaluated the combined effect of anti-browning agents (ascorbic acid, citric acid and L-cysteine) on the inhibition of enzymatic browning of yacon, using Response Surface Methodology. The yacon pretreated with anti-browning agents in concentrations of $15.0 \mathrm{mM}$ for ascorbic acid, $7.5 \mathrm{mM}$ for citric acid and $10.0 \mathrm{mM}$ for L-cysteine was used for the processing of flour. Yacon flour presented an attractive color and good sensory properties, without residual aroma. The contents of FOS and phenolic compounds obtained in yacon flour were $28.60 \mathrm{~g} .100 \mathrm{~g}^{-1}$ and $1.35 \mathrm{~g} .100 \mathrm{~g}$. Yacon flour can be considered as a potential functional food, especially due to high levels of FOS, which allows for its use in formulation of various foods.
\end{abstract}

Keywords: fructooligosaccharide; polyphenol oxidase; ascorbic acid; cysteine; citric acid.

\section{Introduction}

In the recent years, the yacon (Smallanthus sonchifolius) has been increasingly consumed in Brazil because of its nutritional and functional properties. Yacon roots are similar to sweet potatoes, but they have a sweeter taste, a crunchy texture, and can be eaten raw (Reis et al., 2012). They are mainly composed of water and carbohydrates. The major component of yacon root dry matter is fructooligosaccharides (FOS), whereas starch is the major component in most roots. Fructooligosaccharides are fructose polymers containing from 3 to 10 fructose molecules and a terminal glucose molecule. FOS are considered prebiotic because they have limited digestibility and selectively stimulate the growth and activity of intestinal bacteria which promote human health (Ojansivu et al., 2011; Santana \& Cardoso, 2008). Most of the beneficial effects of yacon consumption have been attributed to its content of fructooligosaccharides, phenolic compounds, and antioxidants (Campos et al., 2012).

During the peeling and processing of yacon, the freshly cut surface undergoes rapid browning. This can be related to its phenolic compound contents and the activity of the endogenous polyphenol oxidase (PPO, E.C.1.14.18.1), the main enzyme involved in enzymatic browning of yacon (Padilha et al., 2009; Santana \& Cardoso, 2008). In the presence of molecular oxygen, PPO catalyzes the o-hydroxylation of monophenols to o-diphenols and oxidation of the o-diphenols to o-quinones. Quinones are electrophilic highly reactive molecules that can polymerize leading to the formation of brown or black pigments. This undesirable darkening due to enzymatic oxidation of phenols generally affects nutritional quality and appearance and reduces consumer acceptability of fresh processed products (Lin et al., 2010).

Enzymatic browning in fruits and vegetables can be prevented by adding anti-browning agents such as sulfites, ascorbic acid, and cysteine. The most widespread agents used for control of browning are sulfiting agents. Although the sulfites are very effective and inexpensive, they can be dangerous to human health, especially in asthmatic patients. There is increasing concern regarding allergic reactions to sulfites in certain individuals. Due to adverse health effects, there has been growing interest in the use the non-sulfite anti-browning agents to replace sulfites preservatives (Holzwarth et al., 2012; Ozoglu \& Bayindirli, 2002). A combination of non-sulfite anti-browning agents can be used to preserve fresh processed products.

The control of enzymatic browning during processing is very important to preserve the appearance of yacon flour. Some bakery products, such as cakes and breads (Moscatto et al., 2006; Rolim et al., 2011), have been prepared using yacon flour as raw material. Yacon flour has been considered a food with prebiotic potential because of the high levels of fructooligosaccharides, which allows for its use in formulation of various foods (Rodrigues et al., 2012). In this study, the use of combinations of anti-browning agents (ascorbic acid, cysteine, and citric acid) was investigated in an attempt to find the most effective treatment to inhibit enzymatic browning of yacon flour. Moreover, the chemical composition of yacon flour was evaluated.

\section{Materials and methods}

\subsection{Fresh yacon roots and preparation of crude enzyme extract}

Fresh yacon roots were acquired between July and September 2011 from the Fresh Fruit and Vegetable Supply Center of Goiania, GO (CEASA, Goiania, GO, Brazil); they

\footnotetext{
Received 03 Feb., 2014

Accepted 15 Mar., 2014 (006261)

1 Laboratory of Food Chemistry and Biochemistry, Faculty of Pharmacy, Federal University of Goiás - UFG, Goiânia, GO, Brazil

${ }^{2}$ Faculty of Pharmacy, Federal University of Brasília - UNB, Brasília, DF, Brazil, e-mail: danielaorsi@unb.br

${ }^{*}$ Corresponding author
} 
were produced in the municipality of Botucatu, SP. The roots were selected for their good appearance and sanity, washed under running water, and treated with a sodium hypochlorite $(200 \mathrm{ppm})$ solution for 15 minutes. In order to obtain the enzyme extract, about $40 \mathrm{~g}$ of peeled and sliced yacon containing $1 \%$ polyvinylpyrrolidone (PVP) were homogenized in $40 \mathrm{~mL}$ of $0.05 \mathrm{M}$ phosphate buffer, $\mathrm{pH}$ 7.0, using a blender for $2 \mathrm{~min}$. The mixture was centrifuged at $10.000 \mathrm{rpm}$ for $20 \mathrm{~min}$. at the temperature of $4{ }^{\circ} \mathrm{C}$. The supernatant was used as crude enzymatic extract.

\subsection{Enzyme activity determination}

PPO activity was determined by measuring the rate of increase in absorbance at $420 \mathrm{~nm}$, as described by Lima et al. (2001) with modifications. The reaction mixture consisted of $2.9 \mathrm{~mL}$ of substrate solution $(0.01 \mathrm{M}$ catechol in $0.1 \mathrm{M}$ phosphate buffer $\mathrm{pH} 7.0$ ) and $0.1 \mathrm{~mL}$ of enzyme solution, at $30^{\circ} \mathrm{C}$. Catechol was purchased from Sigma-Aldrich ${ }^{\circledR}$. The blank sample contained $2.9 \mathrm{~mL}$ of substrate solution and $0.1 \mathrm{~mL}$ of phosphate buffer. The increase in absorbance at $420 \mathrm{~nm}$ was recorded for $5 \mathrm{~min}$. One unit of enzyme activity (U) was defined as the amount of the enzyme that caused an increase in absorbance of 0.001 per minute per $\mathrm{mL}$.

\subsection{Effect of $p H$ and temperature}

Optimum $\mathrm{pH}$ for $\mathrm{PPO}$ activity was determined in a $\mathrm{pH}$ range of 3.0 a 10.0 with buffers at concentration of $0.1 \mathrm{M}$, and catechol was used as a substrate at $0.01 \mathrm{M}$. PPO activity was assayed using the standard reaction mixture but changing the buffer. The buffer systems used were citrate phosphate buffer for $\mathrm{pH}$ 3.0, 4.0, and 5.0; phosphate buffer for $\mathrm{pH}$ 6.0, 7.0, and 8.0; borate boric acid buffer for $\mathrm{pH} 9.0$; and $\mathrm{NaOH}$ borate buffer for $\mathrm{pH}$ 10.0. The optimal temperature was determined by measuring PPO activity under standard conditions using catechol $0.01 \mathrm{M}$ in $0.1 \mathrm{M}$ phosphate buffer $\mathrm{pH} 7.0$ as a substrate in the temperature range from $10^{\circ} \mathrm{C}$ to $90^{\circ} \mathrm{C}$. The standard reaction mixture, without the enzyme, was heated to the appropriate temperature in a water bath. After the reaction mixture had come to equilibrium at the selected temperature, the enzyme was added and the enzyme activity was measured.

\subsection{Response Surface Methodology (RSM) and experimental design}

In the statistical experiment, a two level rotatory central composite design $\left(2^{3}\right.$-RCCD) was used with RSM (Barros Neto et al., 2007) to investigate the effect of three independent variables (anti-browning agents) on the inhibition of enzymatic browning (dependent variable). The anti-browning agents tested included ascorbic acid $\left(\operatorname{Vetec}^{\circledR}\right)$, $\operatorname{citric} \operatorname{acid}\left(\operatorname{Synth}^{\circledR}\right)$, and L-cysteine $\left(\operatorname{Vetec}^{\circledR}\right)$. The coded and non-coded levels of each anti-browning agent tested are shown in Table 1.

The design comprised a total of 17 experimental trials that included eight trials for factorial design, six trials for axial points, and three trials for the replication of the central points. The significance of the model was verified applying the analysis of variance (ANOVA) combined with the Fischer test to evaluate whether a given term has a significant effect $(\mathrm{p}<0.05)$. Additionally, the $\mathrm{R}^{2}$ value was calculated to measure the goodness of fit of this regression model. The relationships between the inhibition of enzymatic browning and the effect of combined anti-browning agents were represented in the form of 3D response surface plots. The statistical package software Statistica version 7.0 (StatSoft, USA) was used in the ANOVA analysis and to generate the contour curves.

For the experiments, yacon roots were washed, peeled, and sliced. The yacon slices were dipped in test solutions for $10 \mathrm{~min}$. The concentrations of the anti-browning agents in the test solutions were adjusted according to the experimental design. After $10 \mathrm{~min}$, the yacon slices were removed from the test solutions and crushed using a blender. The mixture was centrifuged at $10.000 \mathrm{rpm}$ for $20 \mathrm{~min}$. at the temperature of $4{ }^{\circ} \mathrm{C}$, and the supernatant was used for enzymatic activity measurements.

\subsection{Yacon flour processing}

For the processing of yacon flour, the yacon roots were washed, peeled, and sliced. The yacon slices were dipped in an aqueous solution containing a combination of anti-browning agents: ascorbic acid $15.0 \mathrm{mM}$, L-cysteine $10.0 \mathrm{mM}$, and citric acid $7.5 \mathrm{mM}$ for $20 \mathrm{~min}$. They were subsequently removed from the anti-browning solution and dried in an air circulating drying oven with at $50^{\circ} \mathrm{C}$ for 2 days. The dried material was then milled using a multiprocessor to obtain the flour. The flour was then vacuum-packed in plastic bags and stored in a dry place.

\subsection{Chemical characterization of yacon flour}

The ash content was determined by calcination in a muffle furnace at $550^{\circ} \mathrm{C}$, model EDGCON 3P 3000 (EDG Equipments, São Carlos, SP, Brazil) to constant weight. Moisture content was determined by drying in a stove at $105^{\circ} \mathrm{C}$ for 4 hours to constant weight (Association of Official Analytical Chemistry, 2006). Total nitrogen was determined by the micro-Kjeldahl method, and the nitrogen content was converted into crude protein by multiplying by the conversion factor of 5.75 (Association of Official Analytical Chemistry, 2006). Total lipids were determined by the Bligh \& Dyer (1959) method. The total

Table 1. Coded and non-coded levels of the experimental variables.

\begin{tabular}{|c|c|c|c|c|c|}
\hline \multirow{2}{*}{ Variables } & \multicolumn{5}{|c|}{ Levels } \\
\hline & $-\alpha$ & -1 & $\mathbf{0}$ & +1 & $+\alpha$ \\
\hline Ascorbic acid (mM) & 0.0 & 2.0 & 5.0 & 9.0 & 15.0 \\
\hline Citric acid (mM) & 0.0 & 1.0 & 3.0 & 5.0 & 7.5 \\
\hline L-cysteine (mM) & 0.0 & 2.0 & 5.0 & 8.0 & 10.0 \\
\hline
\end{tabular}


carbohydrates content was calculated by the subtraction of the sum of the crude protein, total fat, ash and moisture. Reducing sugars were determined using the 3,5-dinitrosalicylic acid method (Miller, 1959). The total fructose was determined by the modified Antrona method (Jermyn, 1956). The FOS content was calculated by the difference between total fructose and reducing sugars. The total phenolic compounds were determined by the Folin-Denis method (Folin \& Denis, 1912). Each parameter was analyzed in triplicate. The results were expressed as mean \pm standard deviation of the independent determinations.

\section{Results and discussion}

\subsection{Effects of $\mathrm{pH}$ and temperature on PPO activity}

The crude enzymatic extract of yacon showed PPO activity of $530 \mathrm{U}$ using catechol $0.01 \mathrm{M}$ in $0.1 \mathrm{M}$ phosphate buffer, $\mathrm{pH} 7.0$, as a substrate at $30^{\circ} \mathrm{C}$. As seen in Figure 1, the optimum $\mathrm{pH}$ of the enzyme was found to be 7.0. In general, most plants show maximum PPO activity at or near neutral $\mathrm{pH}$ values (Mdluli, 2005). For example, it has been reported that the following optimum $\mathrm{pH}$ values: 7.0 for ferula leaf (Erat et al., 2006), 7.0 for marula fruit (Mdluli, 2005), and 6.0 for bayberry fruit (Fang et al., 2007). Unal (2007) reported that the optimum $\mathrm{pH}$ for maximum $\mathrm{PPO}$ activity in plants depends on the purity of enzyme, the type of buffer used, and the substrates used for assay.

The optimum temperature for maximum yacon PPO activity was $20^{\circ} \mathrm{C}$ (Figure 2 ). Above $30^{\circ} \mathrm{C}$, the enzyme activity gradually decreased. At $60{ }^{\circ} \mathrm{C}$, approximately $65 \%$ of PPO activity was lost, and the enzyme showed very little activity between $80^{\circ} \mathrm{C}$

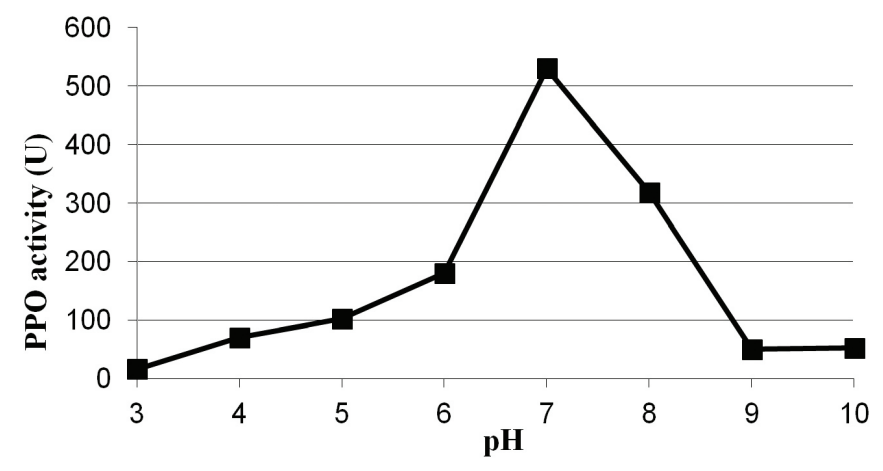

Figure 1. Effect of $\mathrm{pH}$ on $\mathrm{PPO}$ activity of yacon.

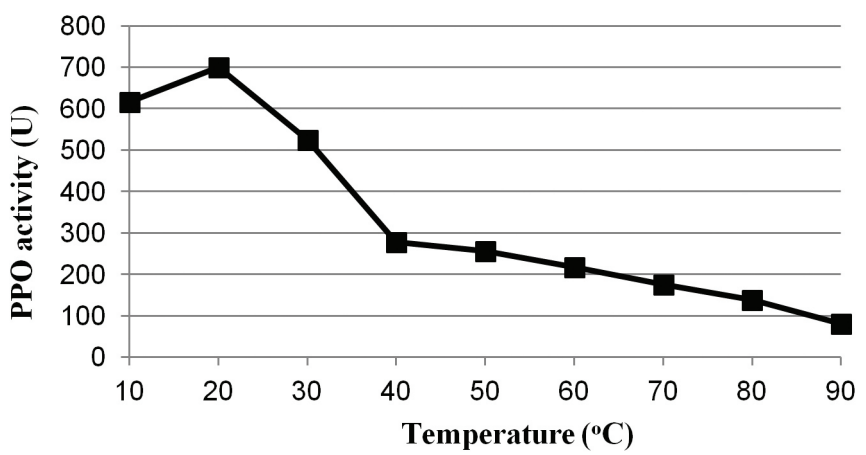

Figure 2. Effect of temperature on PPO activity of yacon. and $90^{\circ} \mathrm{C}$. In general, short exposures to temperatures between $70{ }^{\circ} \mathrm{C}$ and $90^{\circ} \mathrm{C}$ in the tissue are, in most cases, adequate for partial or complete inactivation of PPO (Unal, 2007). However, most fruits and vegetables are heat sensitive, and consequently, high-temperature treatments are inevitably accompanied by losses of texture, color, flavor, and nutritional quality. It has been reported that the optimum temperatures for PPO of peach (Dincer et al., 2002), grape (Dincer et al., 2002), banana (Unal, 2007), and lettuce (Gawlik-Dziki et al., 2008) are 20, 25, 30 , and $35^{\circ} \mathrm{C}$, respectively.

\subsection{Effects of anti-browning agents on inhibition of PPO activity}

The effect of the combinations of ascorbic acid, citric acid, and L-cysteine on the inhibition of enzymatic browning of yacon was evaluated by response surface methodology. The experimental results (enzyme activity) for each of the responses are shown in Table 2. The lower PPO activities were obtained in the experiments $6(148 \mathrm{U})$ and $8(134 \mathrm{U})$, in which the ascorbic acid and L-cysteine were at +1 concentration level. Experiment 13, without L-cysteine, showed the highest enzyme activity (336 U).

L-cysteine has been shown to be an effective PPO inhibitor. L-cysteine prevents browning by reacting with o-quinones to produce stable and colorless products, but high concentrations produce undesirable odor. Citric acid has also been reported to effectively inhibit PPO. Its inhibitory effect is due to the chelation of copper located at the active site of PPO and lowering of the $\mathrm{pH}$ (Holzwarth et al., 2012). Ascorbic acid reduces the o-quinones enzymatically formed, which polymerize to produce brown pigments and delay browning, without affecting the enzymatic activity. The effect of ascorbic acid can be considered temporary because it is oxidized irreversibly by the reaction with pigment intermediates, endogenous enzymes, and metals such as copper (Tortoe et al., 2007).

Table 3 presents the effects of the independent variables on the enzyme activity. As can be seen, the linear main effects of ascorbic acid, citric acid, and L-cysteine produced significant and negative effects in the studied range of 95\% $(\mathrm{p}<0.05)$ confidence level. L-cysteine was the anti-browning agent with the highest effect on the inhibition of yacon PPO. These results indicate that an increase in these parameter values, within the range studied, leads to a lower PPO activity.

The statistical evaluation of the model was performed by the Fisher's test, obtained from analysis of variance (ANOVA), whose results are shown in Table 4. Based on the $F$ test, the model is significant at $95 \%$ confidence level since its $F$ experimental value is higher than the $F$ tabulated value. The $R$-square value (coefficient of determination) provides a measure of how much of the variability observed in the response values could be explained by the experimental factors and their interactions. A good model can explain most of the variations in the response, and the closer the $R$-square value is to 1.0 , the better are the response predictions. In the present study, the adequacy of the model was obtained with a satisfactory coefficient of determination $\left(\mathrm{R}^{2}=0.87\right)$. 
Table 2. Factorial central composite design matrix (23-FCCD) and the experimental results (enzyme activity).

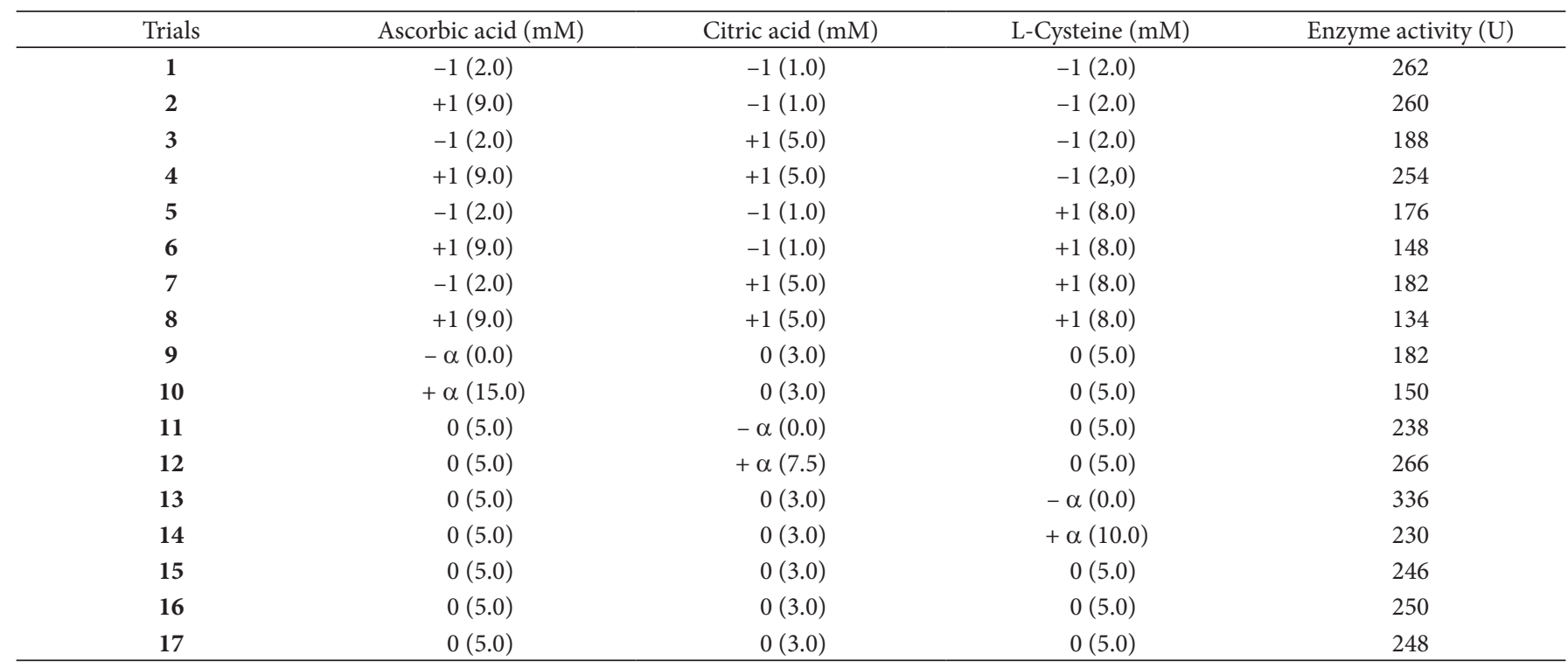

Table 3. Main effects of anti-browning agents on PPO activity.

\begin{tabular}{|c|c|c|c|c|}
\hline & Effect & Std. error & $t(2)$ & $\mathrm{p}$ \\
\hline (1) Ascorbic acid (L) & -9.6388 & 1.0828 & -8.9012 & 0.0123 \\
\hline Ascorbic acid (Q) & -72.5045 & 1.1929 & -60.7763 & 0.0002 \\
\hline (2) Citric acid (L) & -6.0038 & 1.0828 & -5.5443 & 0.0310 \\
\hline Citric acid (Q) & -11.5635 & 1.1929 & -9.6930 & 0.0104 \\
\hline (3) L-cysteine (L) & -73.5929 & 1.0828 & -67.9609 & 0.0002 \\
\hline L-cysteine (Q) & 10.4037 & 1.1929 & 8.7208 & 0.0128 \\
\hline $1 \mathrm{~L} \times 2 \mathrm{~L}$ & 12.0000 & 1.4142 & 8.4853 & 0.0136 \\
\hline $1 \mathrm{~L} \times 3 \mathrm{~L}$ & -35.0000 & 1.4142 & -24.7487 & 0.0016 \\
\hline $2 \mathrm{~L} \times 3 \mathrm{~L}$ & 18.0000 & 1.4142 & 12.7279 & 0.0061 \\
\hline
\end{tabular}

(L) Linear factor; (Q) Quadratic factor.

Table 4. ANOVA for the experimental design used to evaluate the significance of the model.

\begin{tabular}{lcccc}
\hline Variation source & Quadratic sum & Freedom level & Quadratic mean & F test \\
\hline Regression & 37775.67 & 8 & 4721.95 & 1055.30 \\
Residues & 8442.45 & 8 & \\
Lack of fit & 8434.45 & 6 & \\
Pure error & 8.00 & 2 & \\
Total & 46198.12 & 16 & & \\
\hline
\end{tabular}

Coefficient of determination $\mathrm{R}^{2}=0.87$; F $0.95,8.8=3.44$.

After the ANOVA analysis and validation of the study parameters, a model that represents the real relationship between the enzyme activity and the independent variables was established (Equation 1).

$\mathrm{Y}=250-4.82 . \mathrm{X}_{1}-36.25 . \mathrm{X}_{1}^{2}-3.00 . \mathrm{X}_{2}-5.78 . \mathrm{X}_{2}^{2}-36.80 . \mathrm{X}_{3}-$

5.20. $X_{3}^{2}+6.00 \cdot X_{1} \cdot X_{2-} 17.00 \cdot X_{1} \cdot X_{3+} 9.00 \cdot X_{2} \cdot X_{3}$

where $Y$ is the predicted response for enzyme activity, and $X_{1}$, $\mathrm{X}_{2}$ and $\mathrm{X}_{3}$ are the coded values for ascorbic acid, citric acid, and L-cysteine, respectively.

The contour curves, presented in Figure 3, illustrate the interactive effects of the anti-browning agents on inhibition of enzymatic browning of yacon. As can be observed in Figure 3, the lower PPO activities can be obtained using the highest concentrations of anti-browning agents tested: L-cysteine $(10.0 \mathrm{mM})$, citric acid (7.5 mM) and ascorbic acid (15.0 mM).

Although the results indicate that there is a tendency towards a higher inhibition of enzymatic browning of yacon when a higher amount of anti-browning agents is used, it should be noted that the anti-browning agents used in this study affected the sensory food properties at higher dosages. The differences in the mechanism of inhibition of PPO by the different anti-browning agents may allow their use combined at lower concentrations, which can result in an effective control of enzymatic browning. Such combination at lower concentrations is important for the preservation of the sensory properties of 

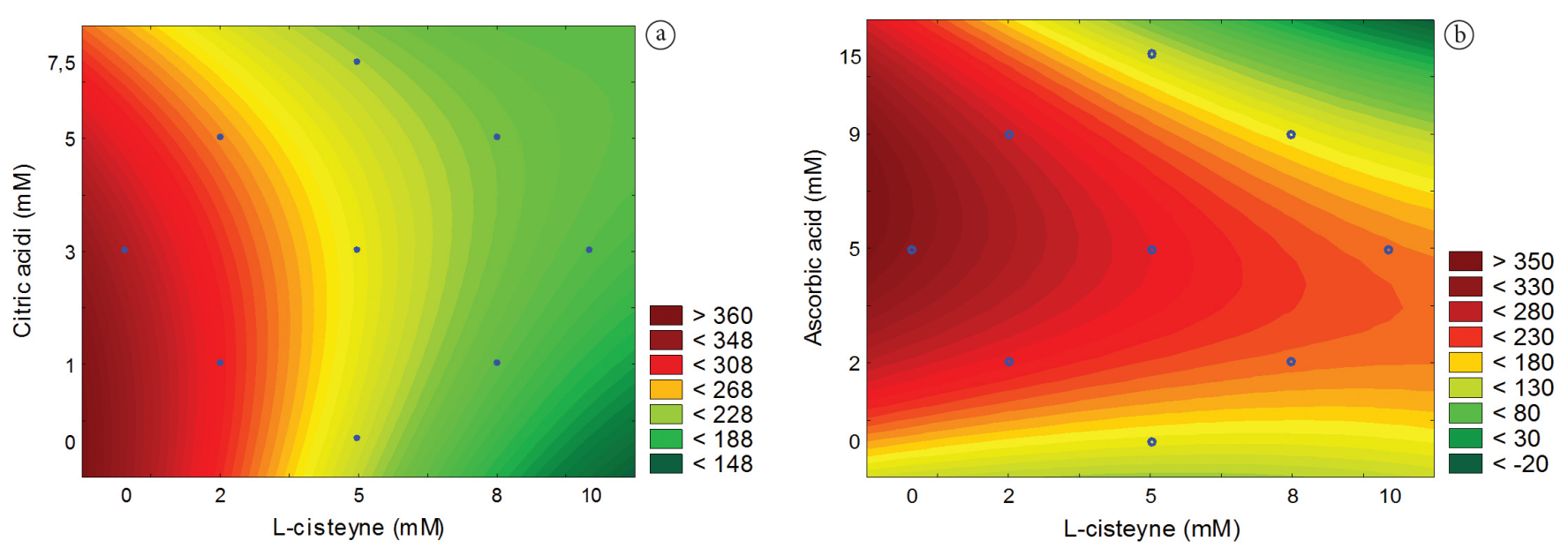

Figure 3. Effects of anti-browning agents on inhibition of enzymatic browning of yacon: a) as a function of citric acid and L-cysteine concentrations; b) as a function of ascorbic acid and L-cysteine concentrations.

Table 5. Chemical composition of yacon flour.

\begin{tabular}{lr}
\hline \multicolumn{1}{c}{ Components } & \multicolumn{1}{c}{ Values } \\
\hline Moisture $\left(\mathrm{g} .100 \mathrm{~g} \mathrm{~g}^{-1}\right)$ & $8.86 \pm 0.23$ \\
Proteins $\left(\mathrm{g} .100 \mathrm{~g}^{-1}\right)$ & $4.34 \pm 0.03$ \\
Total lipids $\left(\mathrm{g} .100 \mathrm{~g} \mathrm{~g}^{-1}\right)$ & $2.11 \pm 0.06$ \\
Ash $\left(\mathrm{g} .100 \mathrm{~g}^{-1}\right)$ & $2.31 \pm 0.08$ \\
Carbohydrates $\left(\mathrm{g} .100 \mathrm{~g} \mathrm{~g}^{-1}\right)$ & $82.38 \pm 0.07$ \\
Total fructose $\left(\mathrm{g} .100 \mathrm{~g}^{-1}\right)$ & $47.30 \pm 0.02$ \\
Reducing sugars $\left(\mathrm{g} .100 \mathrm{~g}^{-1}\right)$ & $18.70 \pm 0.02$ \\
FOS $\left(\mathrm{g} .100 \mathrm{~g}^{-1}\right)$ & $28.60 \pm 0.05$ \\
Phenolic compounds $\left(\mathrm{g} .100 \mathrm{~g}^{-1}\right)$ & $1.35 \pm 0.01$ \\
\hline
\end{tabular}

Results are reported as means \pm standard deviation of three measurements in dry weight basis.

yacon flour. Therefore, the combination chosen for processing yacon flour was the highest concentrations of the anti-browning agents tested in this study: L-cysteine $(10.0 \mathrm{mM})$, citric acid $(7.5 \mathrm{mM})$, and ascorbic acid $(15.0 \mathrm{mM})$.

\subsection{Processing and chemical composition of yacon flour}

The yacon flour prepared from the dried pulp of yacon, previously treated with anti-browning agents at the concentrations of $15.0 \mathrm{mM}$ for ascorbic acid, $7.5 \mathrm{mM}$ for citric acid, and $10.0 \mathrm{mM}$ for L-cysteine showed an attractive color, no residual aroma, and adequate control of enzymatic browning. The chemical analyses of yacon flour were performed 2 days after processing, and the averages of the triplicate results of the chemical analyses are shown in Table 5.

Yacon flour had low mean moisture value, $8.86 \mathrm{~g} .100 \mathrm{~g}^{-1}$. According to Brazilian legislation (Brasil, 2005), flours should contain a maximum of $15.00 \mathrm{~g} .100 \mathrm{~g} \mathrm{~g}^{-1}$ of moisture. The mean values per $100 \mathrm{~g}$ of moisture $(8.86 \mathrm{~g})$, proteins $(4.34 \mathrm{~g})$, ash $(2.31 \mathrm{~g})$, and carbohydrates $(82.38 \mathrm{~g})$ for the yacon flour obtained in this study were similar to the results obtained by Moscatto et al. (2006) for yacon flour used to prepare a chocolate cake: 8.52 g. $100 \mathrm{~g} \mathrm{~g}^{-1}$ of moisture, $4.43 \mathrm{~g} .100 \mathrm{~g}^{-1}$ of proteins, $3.95 \mathrm{~g} .100 \mathrm{~g}^{-1}$ of ash, and $82.74 \mathrm{~g} .100 \mathrm{~g}^{-1}$ of carbohydrates.
The content of FOS obtained in this study ( $\left.28.60 \mathrm{~g} .100 \mathrm{~g}^{-1}\right)$ was similar to that obtained by Rodrigues et al. (2012) for yacon flour (25.70 g.100 g ${ }^{-1}$ of FOS). Campos et al. (2012) evaluated the content of FOS in 35 different yacon accessions, and the results of FOS, expressed in dry matter, varied from 6.4 to $65.0 \mathrm{~g} .100 \mathrm{~g}^{-1}$. According to Campos et al. (2012), variability in FOS content has been related to the endogenous activity of enzymes involved in the synthesis and hydrolysis of FOS in yacon roots. Synthesizing enzyme activities were always higher in rhizophores than in the tuberous roots, while hydrolyzing enzyme activity predominated in the latter. According to Santana \& Cardoso (2008), studies have shown that soon after harvest, there is rapid enzyme hydrolysis of the FOS into simple sugars (glucose, fructose, and sucrose), indicating that to obtain maximum benefit from the FOS, yacon should be consumed soon after harvest.

Another great advantage of yacon roots is its content of phenolic compounds. Phenolic compounds are related to the ability to have antioxidant activity and to prevent the development of cardiovascular diseases and cancer (Campos et al., 2012). The content of phenolic compounds obtained in this study was 1.35 g. $100 \mathrm{~g} \mathrm{~g}^{-1}$. Campos et al. (2012) evaluated the content of phenolic compounds in 35 different yacon accessions, and the results of phenolic compounds, expressed in dry matter, varied from 0.70 to $3.08 \mathrm{~g}$ of chlorogenic acid equivalents. $100 \mathrm{~g}^{-1}$. According to Santana \& Cardoso (2008), compared to other roots, yacon have high levels of phenolic compounds, about $0.2 \mathrm{~g} .100 \mathrm{~g}^{-1}$ of fresh pulp, and it can be compared to some beverages rich in phenolic compounds such as a cup of coffee (0.2-0.5 g) or a cup of tea (0.15-0.2 g).

\section{Conclusions}

Response surface methodology was applied to determine the effect of the combinations of ascorbic acid, citric acid, and L-cysteine on the inhibition of enzymatic browning of yacon. The yacon pulp pre-treated with anti-browning agents at the concentrations of $15.0 \mathrm{mM}$ of ascorbic acid, $7.5 \mathrm{mM}$ of citric acid, and $10.0 \mathrm{mM}$ of L-cysteine was used in the processing of yacon flour, which presented an adequate control of 
enzymatic browning. Yacon flour had satisfactory levels of FOS (28.60 g. $\left.100 \mathrm{~g}^{-1}\right)$ and phenolic compounds (1.35 g. $\left.100 \mathrm{~g}^{-1}\right)$, and it can be considered as a potential functional food, arousing interest for its use in the formulation of various foods such as cakes and breads.

\section{References}

Association of Official Analytical Chemistry - AOAC. (2006). Official methods of analysis (18th ed.). Washington: AOAC.

Barros Neto, B. D., Scarminio, I. S., \& Bruns, R. E. (2007). Como fazer experimentos: pesquisa e desenvolvimento na ciência e na indústria (3. ed.). Campinas: UNICAMP.

Bligh, E. G., \& Dyer, W. J. (1959). A rapid method of lipid extraction and purification. Canadian Journal of Biochemistry and Physiology, 37(8), 911-917. http://dx.doi.org/10.1139/o59-099

Brasil, Agência Nacional de Vigilância Sanitária - ANVISA (2005). Regulamento técnico para produtos de cereais, amidos, farinhas e farelos (Resolução RDC n 263, de 22 de Setembro de 2005). Diário Oficial da República Federativa do Brasil.

Campos, D., Betalleluz-Pallardel, I., Chirinos, R., Aguilar-Galvez, A., Noratto, G., \& Pedreschi, R. (2012). Prebiotic effects of yacon (Smallanthus sonchifolius Poepp. \& Endl), a source of fructooligosaccharides and phenolic compounds with antioxidant activity. Food Chemistry, 135(3), 1592-1599. PMid:22953898. http:// dx.doi.org/10.1016/j.foodchem.2012.05.088

Dincer, B., Colak, A., Aydin, N., Kadioglu, A., \& Guner, S. (2002). Characterization of polyphenoloxidase from medlar fruits (Mespilus germanica L. Rosaceae). Food Chemistry, 77(1), 1-7. http://dx.doi. org/10.1016/S0308-8146(01)00359-4

Erat, M., Sakiroglu, H., \& Kufrevioglu, I. (2006). Purification and characterization of polyphenol oxidase from Ferula sp. Food Chemistry, 95(3), 503-508. http://dx.doi.org/10.1016/j. foodchem.2005.01.044

Fang, Z., Zhang, M., Sun, Y., \& Sun, J. (2007). Polyphenol oxidase from bayberry (Myrica rubra Sieb. Zucc.) and its role in anthocyanin degradation. Food Chemistry, 103(2), 268-273. http://dx.doi. org/10.1016/j.foodchem.2006.07.044

Folin, O., \& Denis, W. (1912). On phosphotungstic-phosphomolybdic compounds as color reagents. Journal of Biological Chemistry, 12, 239-243.

Gawlik-Dziki, U., Złotek, U., \& Swieca, M. (2008); Characterization of polyphenol oxidase from butter lettuce (Lactuca sativa var. capitata L.). Food Chemistry, 107(1), 129-135. http://dx.doi.org/10.1016/j. foodchem.2007.07.068

Holzwarth, M., Wittig, J., Carle, R., \& Kammerer, D. R. (2012). Influence of putative polyphenoloxidase (PPO) inhibitors on strawberry (Fragaria $x$ ananassa Duch.) PPO, anthocyanin and color stability of stored purées. LWT-Food Science and Technology, 52(2), 1-12.

Jermyn, M. A. (1956). A new method for the determination of ketohexoses in presence of aldohexoses. Nature, 177, 38-39. http:// dx.doi.org/10.1038/177038a0

Lima, E. D. P. A., Pastore, G. M., \& Lima, C. A. A. (2001). Purificação da enzima polifenoloxidase (PFO) de polpa de pinha (Annona squamosa L.) madura. Ciência e Tecnologia de Alimentos, 21(1), 98-104. http:// dx.doi.org/10.1590/S0101-20612001000100021
Lin, M., Ke, L. N., Han, P., Qiu, L., Chen, Q. X., Lin, H. T., \& Wang, Q. (2010). Inhibitory effects of p-alkylbenzoic acids on the activity of polyphenol oxidase from potato (Solanum tuberosum). Food Chemistry, 119(2), 660-663. http://dx.doi.org/10.1016/j. foodchem.2009.07.013

Mdluli, K. M. (2005). Partial purification and characterisation of polyphenol oxidase and peroxidase from marula fruit (Sclerocarya birrea subsp. Caffra). Food Chemistry, 92(2), 311-323. http://dx.doi. org/10.1016/j.foodchem.2004.07.026

Miller, G. L. (1959). Use of dinitrosalicylic acid reagent for determination of reducing sugar. Analytical Chemistry, 31(3), 426428. http://dx.doi.org/10.1021/ac60147a030

Moscatto, J. A., Borsato, D., Bona, E., Oliveira, A. S., \& Hauly, M. C. O. (2006). The optimization of the formulation for a chocolate cake containing inulin and yacon meal. International Journal of Food Science \& Technology, 41(2), 181-188. http://dx.doi.org/10.1111/ j.1365-2621.2005.01047.x

Ojansivu, I., Ferreira, C., \& Salminen, S. (2011). Yacon, a new source of prebiotic oligosaccharides with a history of safe use. Trends in Food Science \& Technology, 22(1), 40-46. http://dx.doi.org/10.1016/j. tifs.2010.11.005

Ozoglu, H., \& Bayindirli, A. (2002). Inhibition of enzymic browning in cloudy apple juice with selected antibrowning agents. Food Control, 13(4), 213-221. http://dx.doi.org/10.1016/S09567135(02)00011-7

Padilha, V. M., Rolim, P. M., Salgado, S. M., Livera, A. V. S., \& Oliveira, M. G. (2009). Avaliação do tempo de secagem e da atividade de óxido-redutases de yacon (Smallanthus sonchifolius) sob tratamento químico. Ciência Rural, 39(7), 2178-2184. http://dx.doi.org/10.1590/ S0103-84782009005000142

Reis, F. R., Lenzi, M. K., \& Masson, M. L. (2012). Effect of vacuum drying conditions on the quality of yacon (Smallanthus sonchifolius) slices: process optimization toward color quality. Journal of Food Processing and Preservation, 36(1), 67-73. http://dx.doi.org/10.1111/ j.1745-4549.2011.00555.x

Rodrigues, F. C., Castro, A. S., Rodrigues, V. C., Fernandes, S. A., Fontes, E. A., Oliveira, T. T., Martino, H. S., Luces Fortes Ferreira, C. L. (2012) Yacon flour and Bifidobacterium longum modulate bone health in rats. Journal of Medicinal Food, 15(7), 664-670. PMid:22510044. http://dx.doi.org/10.1089/jmf.2011.0296

Rolim, P. M., Salgado, S. M., Padilha, V. M., Livera, A. V. S., Andrade, S. A. C., \& Guerra, N. B. (2011). Glycemic profile and prebiotic potential "in vitro" of bread with yacon (Smallanthus sonchifolius) flour. Ciência e Tecnologia de Alimentos, 31(2), 467-474. http:// dx.doi.org/10.1590/S0101-20612011000200029

Santana, I., \& Cardoso, M. H. (2008). Raiz tuberosa de yacon (Smallanthus Sonchifolius): potencialidade de cultivo, aspectos tecnológicos e nutricionais. Ciência Rural, 38(3), 898-905. http:// dx.doi.org/10.1590/S0103-84782008000300050

Tortoe, C., Orchard, J., \& Beezer, A. (2007). Prevention of enzymatic browning of apple cylinders using different solutions. International Journal of Food Science \& Technology, 42(12), 1475-1481. http:// dx.doi.org/10.1111/j.1365-2621.2006.01367.x

Unal, M. U. (2007). Properties of polyphenol oxidase from Anamur banana (Musa cavendishii). Food Chemistry, 100(3), 909-913. http:// dx.doi.org/10.1016/j.foodchem.2005.10.048 